\title{
Potopené duše
}

\author{
Hana Hrancová (Brno)
}

Potopené duše. Z tvorby slovenských poetiek v prvej polovici 20. storočia. Zostavila Andrea Bokníková. Bratislava: Aspekt, 2017. 480 s. ISBN 978-80-8151-048-9.

Docentka Andrea Bokníková vytvorila nielen obsahovo výnimočnú, ale aj vizuálne jedinečnú publikáciu. Téma žien - poetiek 20. storočia u nás nie je doposial' podrobne spracovaná, pretože sa jej nikto, okrem Bokníkovej, primárne nevenuje. Základné informácie o autorkách spracovaných v predkladanej publikácii sa nachádzajú v heslách Slovnika slovenskej literatúry z roku 1979, ale časom sa tieto mená z dejín a novších slovníkov vytratili úplne. Dnes opät ožívajú vd’aka rozsiahlemu a podrobnému výskumu autorky. Tá si vybrala náročnú úlohu, sústredila sa na ženy píšuce poéziu, velakrát $\mathrm{z}$ historického vývinu slovenskej literatúry z nejakého dôvodu vynechané, čo samozrejme skomplikovalo aj možnosṫ dohladat si o nich informácie, nehovoriac o ich dielach. Básne jednotlivých poetiek, ktoré sú v tejto čítanke publikované, sú častokrát výsledkom súkromného, nielen archívneho pátrania autorky. Niektoré z nich nevyšli nikdy tlačou a niektoré vyšli v čase svojho vzniku len v periodikách, a aj tie v mnohých prípadoch časom upadli do zabudnutia, pričom sa jedná o jedinečné a esteticky hodnotné básne. Príznačný metaforický názov Potopené duše pre publikáciu bol prevzatý z eseje Ludmily Podjavorinskej, ktorá týmto názvom označila ženy, ktoré história vôbec nespomína, ba dokonca v mnohých prípadoch ich neocenilo ani ich vlastné okolie.

Andrea Bokníková v diele poukazuje aj na to, že väčšinu slovenských poetiek možno rozdelit na základe ich životno-spoločenskej pozície, ktorá ovplyvnila ich tvorbu, na dve skupiny - evanjeličky a katolíčky. Na rozdiel od katoličiek, zvyčajne absolvujúcich len strednú školu, väčšina evanjelických autoriek bola vysokoškolsky vzdelaná, čo však nebolo úplne pravidlom.
Autorka poukazuje na prípady, ktoré sa tomuto striktnému vymedzeniu vymykajú. Demonštruje to na príklade Kamenickej - katolíčky, ktorá mala univerzitné vzdelanie, a na druhej strane Jesenskej - evanjeličky, ktorá nie. V diele je postupne predstavených 12 poetiek charakteristikou ich života a tvorby a uverejnením komplexu zozbieraných „roztrúsených“ básní. V edičných poznámkach k jednotlivým autorkám nájdeme informácie o časovej postupnosti vzniku básní aj o ich redakčných úpravách, čo si žiadalo nelahkú úlohu, a to dohladat originály rukopisov poslaných do vydavatel'stva a ich následné porovnanie s publikovanou verziou. Celú knihu dotvára samotná čítanka, v ktorej sú uverejnené básne predstavených poetiek a velakrát aj listy autoriek redaktorom jednotlivých časopisov posielaných v snahe uverejnit svoje básne vo významných slovenských periodikách. Ide o autorov, ako sú Ján Smrek (Viola Štepanovičová pokorne žiada o uverejnenie svojich básní v časopise Elán), Zora Jesenská (ktorej píše Bela Dunajská so žiadostou o uverejnenie svojej zbierky básní v Živene), Emil Boleslav Lukáč (kde Elena Kamenická žiada o úprimnú a prísnu kritiku a uverejnenie v časopise Tvorba) a d’alší. Väčšina básní uverejnených v čítanke nebola nikdy publikovaná, a teda ani edične upravená. Autorka sa snažila do textov čo najmenej zasahovat', a to pre zachovanie autenticity. Edičné zásahy obmedzila na minimum, jedná sa skôr o drobné pravopisné úpravy, o ktorých podrobne v diele informovala v kapitolke Jazykové úpravy.

Zbierka má ucelenú, prehl’adnú štruktúru s vyváženým pomerom básní a teoretického literárnohistorického pozadia. Výsledné dielo, ktorému predchádzal rozsiahly výskum vo verejných 
Hana Hrancová (Brno)

Potopené duše

aj súkromných archívoch, má vysokú literárnu úroveň a je bezpochyby prínosom v téme modernej poézie 20. storočia.

\section{Mgr. Hana Hrancová}

Ústav slavistiky

Filozofická fakulta, Masarykova univerzita

Arna Nováka 1, 60200 Brno, Česká republika

450832@mail.muni.cz 